\title{
Motivation Level of Student After Implementation Learning Media Based on 3D-Pageflip
}

\author{
Efry Mindayula ${ }^{1, *}$ Hari Sutrisno ${ }^{2}$ \\ ${ }^{1}$ Master of Chemistry Education, Faculty of Mathematics and Natural Sciences, Universitas Negeri Yogyakarta, \\ Indonesia \\ ${ }^{2}$ Department of Chemistry Education, Faculty of Mathematics and Natural Sciences, Universitas Negeri \\ Yogyakarta, Indonesia \\ ${ }^{*}$ Corresponding author.Email: mindayula@gmail.com
}

\begin{abstract}
A learning media based on 3D-Pageflip was applied in learning chemistry to highlight student's motivation level in learning. This study used a pre-experimental with one-shot case study design, just one group was treated during the study. In total, 32 students with grade 10th from one group class at one of senior high school Yogyakarta-Indonesia participated in this study. Data were collected by the student motivation questionnaire consisting of 20 question items, with the results of the validity being in the range, $0.77<\mathrm{MNSQ}<1.33$ and reliability were 0.75 , so it was good to use. Data analysis used descriptive quantitative. The result showed that level student's motivation in learning obtained poor $(3.1 \%)$, moderate $(21.9 \%)$, good $(71.9 \%)$, and very good $(3.1 \%)$ criteria. Generally, the students had good $(71.9 \%)$ level motivation in learning chemistry with learning media based on 3D-Pageflip. Thus the students' motivation to learn chemistry by using 3D-Pageflip-based learning media was in a good category. Therefore, learning media based on 3D-Pageflip can be used as an alternative media that can be used by teachers in the learning process.
\end{abstract}

Keywords: 3D-pageflip, Learning media, Learning chemistry, Motivation.

\section{INTRODUCTION}

The industrial revolution 4.0 is marked by the development of information and communication technology that is increasingly easy to access [1], so affecting all fields of life that have an impact on various sectors. One of them is impacting the education system. the educational system is currently moving forward in the use of technology in learning [2]. On the other hand, education is required to produce humans who can adapt to the challenges of the times. So, this is a challenge for education practitioners to apply technology-based learning to the teaching and learning process. Therefore, education based on technology was an important aspect that can improve students' thinking skills [3], collaboration skills, and practical skills [4], to solve problems in their lives.

The learning process in schools can be an effective way to improve students' thinking skills to solve problems in their lives. However, the results of research TIMSS 2015 which reveal that there are
$55 \%$ of Indonesian students with low science scores with a value of 397 , which is lower than the average TIMSS score (500) for the whole country [5]. One of the factors causing the low ability of students in the field of science is student motivation learning. Motivation is an important factor in the learning process [7]. In line with that, [8] the motivational factor also plays an important role in students' learning and problem-solving skills. Therefore, motivation is closely related to student achievement.

One way to increase student motivation i.e. using media in the learning process. [9] on their research state that the use of learning media based on technology such as chemistry learning provides a new atmosphere for students. In terms of practicality, using learning media based on technology makes it easier for students to access the learning material. [10] stated that media based on technology can facilitate students to organize themselves in the independent learning process. Therefore, the use of technology can also be used in learning to be more 
interactive and engaging students in learning, so the use of media in learning can increase student learning motivation.

One of the learning media that can be applied in the learning process i.e. learning media based on 3DPageflip. 3D-PageFlip Professional allows users to convert Adobe Acrobat PDF, OpenOffice, Microsoft Office to page flipping books with realistic 3D Flash effects and stunning page turning [11]. Previous research has shown that the use of learning media based on 3D-Pageflip has high effectiveness in learning [12]. In line with that, the development of learning media based on 3D-Pageflip was very suitable to use in classroom learning to increase student motivation and understanding [13]. Therefore, the objective of the research was to implement media based on 3D-Pageflip in learning chemistry and to analyze the level of student motivation in learning chemistry.

\section{RESEARCH METHOD}

\subsection{Research Design}

A pre-experimental with one-shot case study design was used in this study. This study was conducted by involving one group $(\mathrm{X})$ in a particular treatment followed by observation or measurement (O) [14]. In this study, the treatment was given by the researcher to all participants i.e. chemistry learning using learning media based on 3D-Pageflip on the quantum concept. Then, the effect of the treatment was observed in the absence of a comparison group.

\subsection{Sample}

The sample in this study were students in one group class at a senior high school in Yogyakarta, Indonesia. The school was chosen because the school has excellent accreditation and facilities to apply technology-based learning, such as internet access, computer laboratories, and LCD projectors in every classroom. The total sample in this study was 32 students of 10th grade in one group class (19 female and 13 male). The sample was chosen by the researcher based on convenience and availability at the time [15]. Then, the sample is students who have come from a class that has been formed by the school itself.

\subsection{Treatment}

The research was designed by applying technology-based media in learning to see student learning motivation. The study was conducted faceto-face meeting before a pandemic situation, it is about October 2019. The study was conducted two weeks (90 minutes per week) at the quantum theory concept. In the first step, the researcher guided all participants to access and use features from the learning media based on 3D-Pageflip, which is the media that will be used in learning. In the second step, all participants were asked to observe the quantum theory concept contained in learning media based on 3D-Pageflip. In the third step, all participants were allowed to ask questions regarding their observations about the concept of quantum mechanics from in learning media based on 3DPageflip. Finally, all participants are asked to answer the questions contained in the learning media, the results of the students' answers can be seen immediately after the questions are finished. After that, all participants were given the questionnaire motivation in learning chemistry after using learning media based on 3D-Pageflip.

\subsection{Data Collection Instrument}

First, learning media based on 3D-Pageflip is an instrument used to see student motivation learning in chemistry learning. 3D-Pageflip is a software-based on flash flipbook that can convert Adobe Acrobat, OpenOffice, Microsoft Office Word, PowerPoint, and Excel PDF files into realistic flipbooks. Then, 3DPageflip has multiple output options for publish, there are; Flash / HTML5, EXE, Zip, 3DP, To FTP Server [11]. Making it easier for users to access products based on 3D-Pageflip. With 3D-Pageflip software, users can create amazing 3D magazines, e-Books, eNewspapers, etc. So, it is suitable for use in making presentations or learning media. Figure 1 presents learning media based on 3D-Pageflip on the quantum concept.

Learning media based on 3D-Pageflip is a media develop $d$ by researchers. The learning media based on 3D-Pageflip is equipped with a test that can be accessed directly by the user and the results can be seen after the user completes the test. In process design, researchers involved several programs such as Adobe Flash, Adobe Photoshop, Corel Draw, and Chemistry- Draw to design concept learning media. Before used in the research, the media were validated by two expert judgment in the chemistry education field and one chemistry teacher. Validation of learning media based on 3D-Pageflip was carried by content validity. 


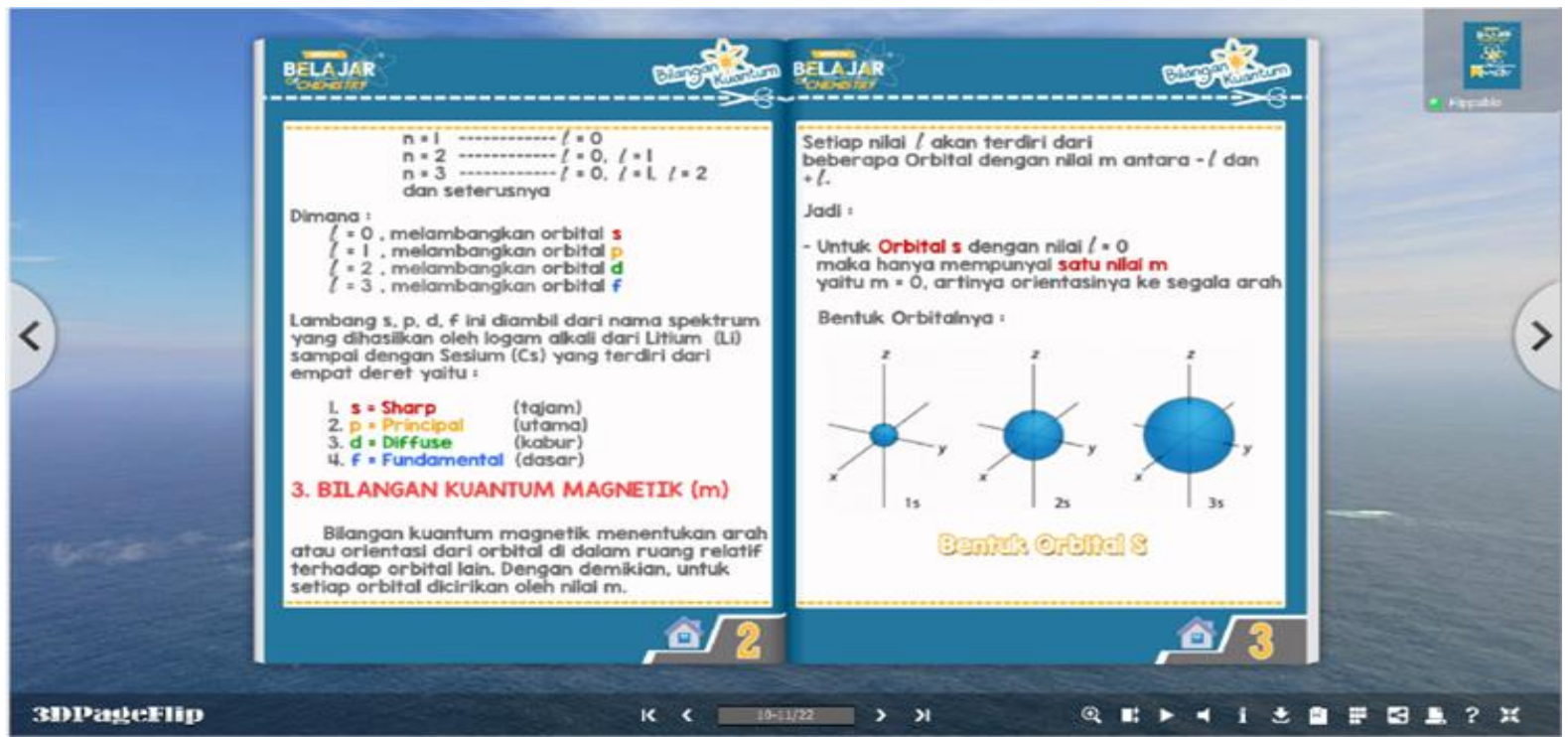

Figure 1 Learning media based on 3D-pageflip

Second, the questionnaire of student learning motivation is an instrument used to determine how students respond to apply learning media based on 3D-Pageflip in chemistry learning. The questionnaire consists of twenty statements including positive statements. The questionnaire was adapted from previous research [16]. Then, the researcher translated the questionnaire into the Indonesian version for the respondents' convenience and better understanding. Furthermore, the researcher modified the questionnaire according to the need of the researcher. This instrument uses a checklist with four Likert type scale (1=strongly disagree until $4=$ strongly agree). This questionnaire includes five aspects used to see the level of student motivation in learning chemistry. Table 1 present the distribution of learning motivation aspects.

The questionnaire was validated before being used in the study. The questionnaire was validated by two expert judgment in the field of chemistry education by content validity based on language and construct aspect. Then, empirical validity was carried out by giving questionnaires to 200 eleventh-grade students of high school. The results of the empirical validity test were analyzed using the Quest program. Decision -making is based on the In-fit MNSQ and the Out-fit MNSQ i.e. ranges $0.77<$ MNSQ <1.33 [17]. The results of the data analysis obtained indicate that all questionnaire items of student motivation are valid to be used. Then, the reliability results obtained were 0.75 . Thus, the student motivation questionnaire is in a good category to use.
Table 1. Learning motivation aspects

\begin{tabular}{|l|l|l|}
\hline Aspect & $\begin{array}{l}\text { Questionnaire } \\
\text { Number }\end{array}$ & Total \\
\hline Intrinsic Motivation & $1 \mathrm{a}, 1 \mathrm{~b}, 1 \mathrm{c}, 1 \mathrm{~d}$ & 4 \\
\hline Self-Efficacy & $2 \mathrm{a}, 2 \mathrm{~b}, 2 \mathrm{c}, 2 \mathrm{~d}$ & 4 \\
\hline Self-Determination & $3 \mathrm{a}, 3 \mathrm{~b}, 3 \mathrm{c}, 3 \mathrm{D}, 3 \mathrm{e}$ & 5 \\
\hline Grade Motivation & $4 \mathrm{a}, 4 \mathrm{~b}, 4 \mathrm{c}, 4 \mathrm{~d}$ & 4 \\
\hline Career Motivation & $5 \mathrm{a}, 5 \mathrm{~b}, 5 \mathrm{c}$ & 3 \\
\hline
\end{tabular}

\subsection{Data Analysis}

Data analysis techniques in this study used descriptive quantitative analysis with the SPSS program. The steps of data analysis were to calculate the total score of each student, calculate the percentage score of each student and categorize the calculation results. Then, the data are classified into five criteria following the categories adapted from [18]. The five criteria consist of very good, good, moderate, poor, very poor criteria. The questionnaire consisted of 20 items with a maximum score of 4 on each item so that the maximum ideal score for this aspect of the analysis was 80 . The ideal criteria were carried out to determine which students considered the five criteria for the level of students' chemistry learning motivation. The five criteria consist of: if ' $x$ ' $>65$ indicated very good criteria; within the range of $55<$ ' $x$ ' $\leq 65$ indicated good criteria; within the range of $45<$ ' $x$ ' $\leq 55$ indicated moderate criteria, within the range of $35<$ ' $x$ ' $\leq 45$ indicated poor criteria; and if ' $x$ ' $\leq 35$ indicated very poor criteria. The five criteria included to SPSS program for analysis data. 


\section{RESULT AND DISCUSSION}

The focus of the research in this study was to measure student motivation after implement ing learning media-based 3D-Pageflip in chemistry learning. Learning motivation is one indicator of the success of a learning process. Three main factors influence the acquisition of knowledge, namely age, personality, and motivation. In addition, motivation is the most significant factor in acquiring knowledge [19]. In the research, student learning motivation was measured using a questionnaire learning motivation, after applying chemistry learning using learning media based on 3D-Pageflip. On the q uestionnaire learning consists of five aspects of learning motivation i.e intrinsic motivation, self-eff icacy, self-determination, grade motivation, and career motivation. Then, the questionnaire was analyzed by descriptive quantitative with SPSS program. Table 2 presents the result of the analysis with the SPSS program

Table 2. Result of analysis with SPSS Program

\begin{tabular}{|l|l|l|l|}
\hline & Freq. & Percent & $\begin{array}{l}\text { fumulative } \\
\text { Percent }\end{array}$ \\
\hline Poor Criteria & 1 & 3.1 & 3.1 \\
\hline Moderate Criteria & 7 & 21.9 & 25.0 \\
\hline Good Criteria & 23 & 71.9 & 96.0 \\
\hline $\begin{array}{l}\text { Very Good } \\
\text { Criteria }\end{array}$ & 1 & 3.1 & 100.0 \\
\hline Total & 32 & 100.0 & \\
\hline
\end{tabular}

The results of the questionnaire analysis using the SPSS program (Table 2) show that the level of student motivation consists of the poor criteria $(3.1 \%$ with 1 frequency), good criteria (71.9\% with 23 frequency), moderate criteria $(21.9 \%$ with 7 frequencies), and very good criteria $(3.1 \%$ with 1 frequency). However, overall the student learning motivation has good criteria. Therefore, using learning media based on 3D-Pageflip in learning chemistry can be able to influence student learning motivation in the learning process. The results of this study confirm previous research on the use of media in influencing student learning motivation. The use of technology is a means that can be used to motivate students in the learning process, to be able to positively influence student achievement in learning [20]. Then, the use of technology makes learning more relevant, meaningful, and fun; thus, students' academic frustration decreased [21].

Therefore, the integration of technology into the learning process has an impact on student motivation. The focus in this study is more on the level of student motivation in learning when apply of learning media based on technology in the learning process. Overall, students have good motivation in learning using learning media based on 3D-Pageflip. The results with this category of good motivation are in line with research conducted by [22] show that students with good motivation will have an impact on good student learning outcomes as well. The term motivation comes from the Latin "movere" (to move). Then, the term moving has been reflected in the general idea of motivation as something that keeps us going, keeps us working, and helps us get things done [23]. In the learning process, student learning motivation is an important factor, so that the concepts taught by the teacher can be understood properly. Students who have the motivation to learn a material will use a higher cognitive process in learning so that these students will easily understand the material being studied [24]. The role of the teacher in the learning process also affects student learning motivation [25]. There are several ways that teachers can do in increasing student motivation, such as; There are several ways that can be done by teachers in increasing student motivation, such as; creating a new atmosphere in the classroom [22], using methods and strategies in learning [26], and using technologybased media in learning [20].

Based on the result in this research, using learning media based on technology is one way that teachers can do to increase student motivation in learning. There was a difference in student learning motivation between the experimental class applying the CTL approach-based audio-visual media has the highest score of the students' learning motivation than the control class not applying the CTL approach-based audio-visual media in learning chemistry [8]. Then, using media can increase student motivation in learning [27]. Therefore, students with high levels of learning motivation can produce good learning outcomes and academic achievements. In addition, students who show high motivation in the learning process will be able to understand the chemical concepts being studied [28]. In other words, academic achievement and learning outcomes are in line with the level of student motivation. There is a correlation between high student motivation and academic achievement. The higher the student's motivation to learn, the better the student's academic performance and achievement [24]. Thus, the result of this study indicated that motivation was one of the very important factors for the learning process and academic achievement by students [29]. 


\section{CONCLUSION}

In this research, the researcher used learning media based on 3D-Pageflip to find the level of motivation criteria in learning chemistry. The result of this study showed that using learning media based on 3D-Pageflip can find students' level motivation in learning, i.e. good criteria. Therefore, using media in learning can be able to improve student learning motivation. The student with a level of high learning motivation will have good learning achievement. The higher motivation is in line with the better student's achievement. However, this research is only limited to see the level of student motivation using mediabased 3D-Pageflip, it is not continued to find the results of student learning achievement. Researchers hope to the next researchers, who are related to this research, can develop this research so that students' academic achievements can be known.

\section{ACKNOWLEDGMENTS}

Thanks to all participants, expert judgment, and chemistry teacher in the research, and thanks to reviewers for the suggestions and feedback.

\section{REFERENCES}

[1] D. Lase, Education and Industrial Revolution 4.0, Jurnal Handayani 10(1) (2019) 48-62. DOI: https://doi.org/10.24114/jh.v10i1.14138

[2] A. Wiyarsi, N. Fitriyana, J. Ikhsan, Using Technology in Hydrocarbon Topics: A Profile on Students' Self-Regulated Learning, Journal Education Gift Young Science 7(4) (2019) 983998. DOI: https://doi.org/10.17478/jegys.616947

[3] K. Kereluik, P. Mishra, C. Fahnoe, L. Terry, What Knowledge is of Most Worth: Teacher Knowledge for $21^{\text {st }}$ Century Learning, Journal of Digital Learning in Teacher Education 29(4) (2014) 127-140. DOI: https://doi.org/10.1080/21532974.2013.1078471 $\underline{6}$

[4] D. Vanada, Practically Creative: The Role of Design Thinking as An Improved Paradigm for 21st Century Art Education, Techne: Research in Sloyd Education and Craft Science A 21(2) (2014) 21-33.

[5] I.V.S. Mullis, M.O. Martin, P. Foy, M. Hooper, TIMSS Advanced 2015 International Results in Advanced Mathematics and Physics, Boston College, Jan. 2016. Accessed on: Oct. 24, 2020,
[Online].

Available:

http://timssandpirls.bc.edu/timss2015/internation al-results/advanced/

[6] Sugiyanto, M. Badarudin, Herpratiwi, S. Untung, Sabarudin, The Influence of Learning Motivation on The Learning Outcomes of Vocational Students at Lampung University, International Journal of Advanced Science and Technology 29(5) (2020) 133-140.

[7] B.B. Meyer, A. Kaplan, Motivational Influences on Transfer of Problem-Solving Strategies, Contemporary Educational Psychology 30(1) (2005) 1-22. DOI: https://doi.org/10.1016/j.cedpsych.2004.06.003

[8] S. Khairani, E. Rohaeti, M. Fatharani, The Development of Audio-Visual Media with Contextual Teaching Learning Approach to Improve Learning Motivation and Critical Thinking Skills, Psychology, Evaluation, and Technology in Educational Research 2(2) (2019) 98-114.

DOI: http://dx.doi.org/10.33292/petier.v2i2.12

[9] C. Wisetsat, P. Nuangchalerm, Enhancing Innovative Thinking of Thai Pre-Service Teachers through Multi-Educational Innovations, Journal for The Education of Gifted Young Scientists 7(3) (2019) 409-419. DOI: http://dx.doi.org/10.17478/jegys.570748

[10] A. Kitsantas, Fostering College Student's SelfRegulated Learning with Learning Technologies, Hellenic Journal of Psychology 10(3) (2013) 48-59.

[11] D. Pratama, S. Rianti, U. Usmeldi, S. Syafriani, Preliminary analysis of learners in developing students book oriented research based learning models using 3D-pageflip professionals on science lessons junior high school, in: Journal of Physics Conference Series, vol. 1185, IOP Publishing, Bristol, 2019, pp. 1-7. DOI: https://doi.org/10.1088/17426596/1185/1/012125

[12] S. Raihan, Haryono, F. Ahmadi, Development of Scientific Learning E-Book Using 3DPageflip Professional Program, Innovative Journal of Curriculum and Educational Technology 7(1) (2019) 7-14. DOI: https://doi.org/10.15294/ijcet.v7i2

[13] U. Yelianti, M. Munif, M. Sanjaya, Development of Electronic Learning Media 
Based 3D-Pageflip on Subject Matter of Photosynthetis in Plant Physiology Course, Jurnal Pendidikan Biologi 4(2) (2018) 121-134. DOI: https://doi.org/10.22437/bio.v4i2.5858

[14] J.W. Creswell, J.D. Creswell, Research Design; Qualitative, Quantitative and Mixed Methods Approaches, Sage Publication, 2018.

[15] J.W. Creswell, Educational Research: Planning, Conducting, and Evaluation Quantitative and Qualitative Research, Pearson, 2015.

[16] S.B. Chumbley, J.C. Haynes, K.A. Stofer, A Measure of Students' Motivation to Learn Science through Agricultural STEM Emphasis, Journal of Agricultural Education 56(4) (2015) $107-122$.

DOI: http://dx.doi.org/10.5032/jae.2015.04107

[17] R.J. Adams, S.T. Khoo, Quest: The Interactive Test Analysis System, ACER, 1996.

[18] N.E. Gronlund, R.L. Linn, Measurement and Evaluating in Teaching, Macmillan Publishing Company, 2009.

[19] V. Cook, Linguistics and Second Language Acquisition, Macmillan Publishers Ltd, 2000.

[20] T. Heafner, Using Technology to Motivate Students to Learn Social Studies, Contemporary Issues in Technology and Teacher Education 4(1) (2004) 42-53.

[21] J. Rochowicz, The Impact of Using Computers and Calculators on Calculus Instruction: Various Perceptions, Journal of Computer in Mathematics and Science 15(4) 1996 423-435. DOI:

https://dl.acm.org/doi/10.5555/246641.246658

[22] R. Bakar, The Effect of Learning Motivation on Student's Productive Competencies in Vocational High School, West Sumatra, International Journal of Asian Social Science 4(6) (2014) 722-732.

[23] D. Schunk, Motivation in Education: Theory, Research, and Applications, Pearson, 2013.

[24] A. Riswanto, S. Aryani, Learning Motivation and Student Achievement: Description Analysis and Relationships Both, International Journal of Counseling and Education 2(1) (2017) 42-47. DOI: https://doi.org/10.23916/002017026010
[25] E. Vero, E. Puka, The Importance of Motivation in An Educational Environment, Formazione \& Insegnamento 15(1) (2017) 57-66.

[26] D. Rachmawati, E. Rohaeti, The Effect of Science, Technology, and Society on Critical Thinking Skills and Learning Motivation of Student, Jurnal Pendidikan Matematika dan Sains 6(1) (2018) 29-39. DOI: https://doi.org/10.21831/jpms.v6i1

[27] Z. Muhsinin, H. Wildan, Muntari, Development of Animation Media to Improve Students' Learning Motivation and Chemistry Learning Achievement at SMAN 4 Praya, Jurnal Pengkajian Ilmu dan Pembelajaran Matematika dan IPA 1(2) (2013) 148-155. DOI: https://doi.org/10.33394/j-ps.v1i2.1013

[28] T.T. Lee, K. Osman, Interactive multimedia module in the learning of electrochemistry: effects on students' understanding and motivation, in: Procedia, vol. 46, Elsevier, Amsterdam, 2012, pp. 1323-1327. DOI: https://doi.org/10.1016/j.sbspro.2012.05.295

[29] A.J. Elliot, C.S. Dweck, Handbook of Competence and Motivation, Guilford Press, 2005. 